\title{
Flectobacillus marinus (Raj) comb. nov., a Marine Bacterium Previously Assigned to Microcyclus
}

\author{
RENEÉ BORRALL AND JOHN M. LARKIN \\ Department of Microbiology, Louisiana State University, Baton Rouge, Louisiana 70803 \\ Microcyclus marinus Raj appears to be more closely related to the genus \\ Flectobacillus Larkin et al. than to the genus Microcyclus Ørskov. By reason of \\ the transfer to the genus Flectobacillus, the name of the species becomes \\ Flectobacillus marinus (Raj) comb. nov. Minor modifications in the description \\ of the genus Flectobacillus are required by this change.
}

Until recently the genus Microcyclus Ørskov 1928 had been a poorly defined group consisting of three species of gram-negative, respiratory, strictly aerobic, nonmotile, curved cells. The cells may curve enough so that the ends of the cells overlap to produce a ring, or doughnut, appearance. That this genus consisted of several dissimilar organisms and was in need of realignment was pointed out several times $(1-3,5)$. Larkin et al. (3) undertook this task and made the following changes. Firstly, the genus Spirosoma Migula 1894 was reintroduced, as was suggested by Claus et al. (1), and Microcyclus flavus Raj 1970 became Spirosoma linguale. The description of the genus Spirosoma was emended. Secondly, the new genus Flectobacillus was created to contain $M$. major Gromov 1963. Thirdly, the genus Microcyclus was redefined and contained only one species, $M$. aquaticus. Each genus thus consisted of one of the three species that appeared in Bergey's Manual, 8th ed. (5).

While this reclassification of the genus was in press, Raj (4) reported the characteristics of a new species of Microcyclus for which he proposed the name $M$. marinus. The description of this organism as prepared by Raj (4) closely fits the description of the new genus Flectobacillus, and we have carried out an investigation to see if $M$. marinus should be reclassified as a species of Flectobacillus.

The type strain of $M$. marinus, American Type Culture Collection (ATCC) number 25205, was obtained from H. D. Raj. The type strain of Flectobacillus major, which is the type species of the genus Flectobacillus, was obtained through the courtesy of $\mathrm{D}$. Claus of Göttingen, Germany, from the Deutsche Sammlung von Mikroorganismen (DSM) with the accession number 109. The two organisms were first compared on the basis of their published descriptions and then on the basis of their characteristics as determined in the laboratory. The techniques used for the growth and determination of the characteristics of the organisms were published previously $(3,4)$. Our laboratory results (Table 1) agreed with the published descriptions of both strains.

Cells of the two organisms are very similar in morphology, ranging from nearly straight rods to coiled filaments. They are nonmotile, and on Microcyclus-Spirosoma agar (3) supplemented with $3.0 \% \mathrm{NaCl}$ for $M$. marinus they produce a non-water-soluble pink pigment. They are both respiratory in metabolism and produce acid aerobically from the same carbohydrates and alcohols. The guanine-plus-cytosine contents of the deoxyribonucleic acids are 38.3 and $39.5 \mathrm{~mol} \%$ for $M$. marinus and $F$. major, respectively. The guanine-plus-cytosine content of the deoxyribonucleic acid of $M$. aquaticus, the type species of Microcyclus, ranges from 66.3 to $68.4 \mathrm{~mol} \%$.

In many additional characters, $M$. marinus and $F$. major are similar, and it seems clear that $M$. marinus should be transferred to the genus Flectobacillus. Differences between the two species do exist in that $F$. major is a larger, more loosely coiled organism and is more versatile than $M$. marinus in its hydrolytic reactions and less versatile in its ability to utilize single carbon sources $(3,4)$. In addition, $\boldsymbol{M}$. marinus requires at least $1.5 \% \mathrm{NaCl}$ in the medium for good growth to occur. Because of these differences with $F$. major, we feel that $M$. marinus is distinct from $F$. major and that it should be recognized as a separate species. We propose, therefore, that $M$. marinus Raj be transferred to Flectobacillus as Flectobacillus marinus (Raj) comb. nov.

Because $M$. marinus is smaller than $F$. major and has a slightly lower guanine-plus-cytosine content in its deoxyribonucleic acid, the description of Flectobacillus should be emended accordingly. All other characteristics in the generic description remain unchanged. An emended description of this genus follows.

Genus Flectobacillus Larkin et al. 1977 
TABLE 1. Comparison of the characteristics of the type strains of $M$. marinus and $F$. major

\begin{tabular}{|c|c|c|c|c|c|}
\hline Characteristic & $\begin{array}{l}\text { M. marinus } \\
\text { ATCC } 25205\end{array}$ & $\begin{array}{c}\text { F. major DSM } \\
109\end{array}$ & Characteristic & $\begin{array}{l}\text { M. marinus } \\
\text { ATCC } 25205\end{array}$ & $\begin{array}{c}\text { F. major DSM } \\
109\end{array}$ \\
\hline Gram reaction & - & - & Sorbitol & - & - \\
\hline Pink pigment produced & + & + & Utilization of single carbon & & \\
\hline Fluorescence & - & - & sources: & & \\
\hline Motility & - & - & Acetate & + & - \\
\hline Mol\% guanine plus cyto- & 38.3 & 39.5 & Benzoate & - & - \\
\hline sine & & & Citrate & + & - \\
\hline Formation of coils & + & + & Formate & - & - \\
\hline Formation of filaments & + & + & Malonate & + & - \\
\hline Cell size: & & & Succinate & + & + \\
\hline Length $(\mu \mathrm{m})$ & $2.0-5.0$ & $2.0-5.0$ & Tartrate & + & - \\
\hline $\operatorname{Diam}(\mu \mathrm{m})$ & $0.3-0.7$ & $0.6-1.0$ & Hydrolytic activity on: & & \\
\hline Diam of rings $(\mu \mathrm{m})$ & $0.8-2.0$ & $5.0-10.0$ & Casein & - & - \\
\hline Filament length $(\mu \mathrm{m})$ & $>50$ & $>50$ & Cellulose & - & - \\
\hline Acid produced aerobically & & & Chitin & - & - \\
\hline from: & & & Gelatin & - & + \\
\hline Pentoses & & & Tributyrin & - & + \\
\hline Arabinose & + & + & Starch & - & + \\
\hline Xylose & + & + & Production of specific en- & & \\
\hline Methyl pentose: rham- & + & + & zymes or reactions: & & \\
\hline nose & & & Catalase & + & + \\
\hline Hexoses & & & Oxidase & + & + \\
\hline Fructose & + & + & Urease & - & + \\
\hline Galactose & + & + & Hemolysin & - & - \\
\hline Glucose & + & + & $\mathrm{H}_{2} \mathrm{~S}$ production & - & - \\
\hline Mannose & + & + & Indole & - & - \\
\hline Glucoside: salicin & + & + & Methyl red & - & - \\
\hline Disaccharides & & & Voges-Proskauer & - & - \\
\hline Lactose & + & + & $\mathrm{NO}_{3}$ reduction & - & - \\
\hline Maltose & + & + & Antibiotic susceptibility to: & & \\
\hline Sucrose & + & + & Ampicillin, $10 \mu \mathrm{g}$ & + & + \\
\hline Trehalose & + & + & Cephalothin, $30 \mu \mathrm{g}$ & + & + \\
\hline Trisaccharide: raffinose & + & + & Erythromycin, $15 \mu \mathrm{g}$ & + & + \\
\hline Polysaccharide: inulin & + & + & Kanamycin, $30 \mu \mathrm{g}$ & - & - \\
\hline Alcohols & & & Neomycin, $30 \mu \mathrm{g}$ & - & - \\
\hline Glycerol & - & - & Penicillin G, $10 \mathrm{U}$ & - & + \\
\hline Dulcitol & - & - & Streptomycin, $10 \mu \mathrm{g}$ & - & + \\
\hline Mannitol & - & - & Tetracycline, $30 \mu \mathrm{g}$ & + & + \\
\hline
\end{tabular}

emend. (Flec.to.ba.cil lus. L. V. flecto to curve; L. n. bacillus a little staff, rod; M. L. masc. n. Flectobacillus curved rod.)

Straight to curved rods, the degree of curvature varying among individual cells within a culture; the most abundantly occurring cells are those in the shape of the letter "C." The cells measure 0.3 to 1.0 by 1.0 to $5.0 \mu \mathrm{m}$. Long, sinuous filaments up to $50 \mu \mathrm{m}$ long are present. Rings 1.5 to $10.0 \mu \mathrm{m}$ in outer diameter are formed by overlapping of the ends of a cell. Coils or helical spirals are infrequently formed. Gram negative. Nonmotile. Not flexible. Resting stages are not known. Colonies on Microcyclus-Spirosoma agar (with $3.0 \% \mathrm{NaCl}$ for marine forms) contain a pale pink or rose-colored, non-water-soluble pigment.

Metabolism is respiratory; acids are produced aerobically from a variety of carbohydrates. Strictly aerobic. Chemoorganotrophic.
The guanine-plus-cytosine content of the deoxyribonucleic acid ranges from 38.3 to 40.3 mol\% (buoyant density or thermal denaturation).

The type species is $F$. major (Gromov) Larkin et al. 1977.

\section{ACKNOWLEDGMENT}

This work was supported by a grant from the Graduate Research Council of Louisiana State University.

\section{REPRINT REQUESTS}

Address reprint requests to: Dr. John M. Larkin, Department of Microbiology, Louisiana State University, Baton Rouge, LA 70803.

\section{LITERATURE CITED}

1. Claus, D., J. E. Bergendahl, and M. Mandel. 1968. DNA base composition of Microcyclus species and organisms of similar morphology. Arch. Mikrobiol. 63:26-28. 
2. Konopka, A. E., R. L. Moore, and J. T. Staley. 1976. Taxonomy of Microcyclus and other nonmotile, ringforming bacteria. Int. J. Syst. Bacteriol. 26:505-510.

3. Larkin, J. M., P. M. Williams, and R. Taylor. 1977. Taxonomy of the genus Microcyclus Ørskov 1928: reintroduction and emendation of the genus Spirosoma Migula 1894 and proposal of a new genus, Flectobacil lus. Int. J. Syst. Bacteriol. 27:147-156.

4. Raj, H. D. 1976. A new species: Microcyclus marinus. Int. J. Syst. Bacteriol. 26:528-544.

5. Staley, J. T. 1974. Genus Microcyclus, p. 214. In R. E. Buchanan and N. E. Gibbons (ed.), Bergey's manual of determinative bacteriology, 8 th ed. The Williams and Wilkins Co., Baltimore. 